\title{
Tingkat Pengetahuan Obat Kuat Kepala Rumah Tangga Di Lamben-Segala Anyar, Lombok Tengah
}

\author{
Miza Asrori' ${ }^{1)}$, Lalu Jufriadi' ${ }^{2}$, Hasrun Ningsih ${ }^{3)}$ \\ Email: mizaasrori@outlook.com \\ 1) Mahasiswa Program Studi Farmasi / Universitas Qamarul Huda Badaruddin Bagu \\ ${ }^{2)}$ Program Studi Farmasi / Universitas Qamarul Huda Badaruddin Bagu \\ 3) Program Studi Kebidanan / Universitas Qamarul Huda Badaruddin Bagu
}

\begin{abstract}
ABSTRAK
Tujuan penelitian ini untuk mengetahui tingkat pengetahuan tentang obat kuat pada kepala rumah tangga di Lamben-Segala Anyar, Kecamatan Pujut Kabupaten Lombok Tengah dan mengidentifikasi tingkat pengetahuan tentang aturan pemakaian, cara penggunaan, dan efek samping. Penelitian ini merupakan penelitian deskriptif, dan akan dilihat tingkat pengetahuan tentang obat kuat. Jumlah responden sebanyak 93 kepala rumah tangga pengambilan sampel menggunakan sampling jenuh. Teknik pengambilan data melalui wawancara menggunakan kuesioner, selanjutnya data dianalisis secara deskriptif. Hasil penelitian tingkat pengetahuan tentang obat kuat didapatkan responden berpengetahuan tinggi $29 \%$, responden berpengetahuan sedang 56\%, dan $15 \%$ responden berpengetahuan rendah.
\end{abstract}

Kata kunci: Obat kuat, tingkat pengetahuan, Segala Anyar.

\begin{abstract}
The purpose of this research is to know level of knowledge about Aprosidiac in Lamben-Anyar, Pujut, Central Lombok Regency, and identification level of knowledge of rule of use, way of use, and side effect. This study is a descriptive research, and will be seen from the knowledge of strong drugs. The number of respondents was 93 households taking samples using saturated sampling. Technique of collecting data through interview using questioner, then data analyzed descriptively. The results of research on knowledge level of strong drugs were obtained by high knowledge respondents $29 \%$, medium knowledgeable respondents $56 \%$, and $15 \%$ of respondents were knowledgeable low.
\end{abstract}

Keywords: Aprosidiac, level of knowledge, Segala Anyar.

\section{A. LATAR BELAKANG}

Obat merupakan sesuatu komposisi berbagai bahan yang dimanfaatkan untuk menyembuhkan penyakit atau kelainan tubuh dan rohani manusia. Selain itu obat digunakan untuk menetapkan diagnosa serta mengurangi gejala buruk yang dialami tubuh[1]. Aprodisiac atau yang biasa disebut obat kuat adalah bahan yang diklaim menambah dorongan seksual manusia (sexual desire) dan menambah kenikmatan bercinta dengan pasangan[2].

Obat dapat menyembuhkan jika berfungsi sebagaimana mestinya dan dapat pula menjadi racun jika pemberian dosis dan indikasi yang salah. Obat itu akan bersifat sebagai obat apabila tepat digunakan dalam pengobatan suatu penyakit dengan dosis dan waktu yang tepat. Jika obat melebihi dosis yang semestinya maka akan terjadi keracunan dan jika dosisnya kurang maka tidak terjadi proses penyembuhan[3].

Faktor-faktor penyebab kesalahan dalam pemakaian obat adalah kebanyakan pasien yang menghentikan pengobatan ketika sudah merasa tubuhnya sedikit membaik. Obat-obat membahayakan jika pemakaiannya salah dan diperkirakan 30\% hingga 50\% dari semua aturan pemakaian obat tidak dituruti sebagaimana semestinya serta 5000 tempat di rumah sakit 
umum tiap harinya ditempati oleh orang-orang yang memakai obat merek tidak sebagaimana mestinya dan pasien menghentikan pengobatan ketika merasa lebih baik dan bukannya menyelesaikan seluruh pengobatan sesuai pengobatan yang dianjurkan oleh dokter[4].

Salah satu yang sedang marak diperbincangkan adalah peran dan manfaat obatobatan yang mampu mendorong aktivitas seks seperti: Viagra (Pfizer Inc), Levitra (Bayer AG), Cialis (Eli Lilli \& Corporation), Irex Max (Bintang Toedjoe). Di Amerika Serikat sekitar $11,5 \%$ pria telah mengalami disfungsi ereksi. Disfungsi ereksi dapat menyerang pria dewasa baik tua dan muda. Dokter Mark Geronimo menyatakan bahwa pria yang berkonsultasi mengenai disfungsi ereksi dan berbagai kondisi seksnya adalah pria yang berusia relatif muda. Dokter Mark Geronimo juga menyatakan bahwa pada pria yang berusia muda, penyebab terbanyaknya adalah faktor psikologis. Disfungsi ereksi merupakan kondisi yang menyertai berbagai penyakit yang lainnya seperti: darah tinggi, stroke, diabetes melitus, serangan jantung, rematik, dan tumor/kanker prostat.

Hingga saat ini terdapat lebih dari 152 juta pria di dunia yang mengalami disfungsi ereksi, dan jumlahnya diperkirakan akan menjadi 322 juta jiwa pada tahun 2025. Itu berarti terjadi lonjakan hingga 170 juta jiwa. Di Asia, posisi pertama diduduki oleh Republik Rakyat Cina sebesar $25 \%$ dan posisi kedua diduduki oleh Indonesia sebesar $21 \%$ dari jumlah penduduk pria di Asia. Ditemukan pula bahwa hampir setengah dari pria Indonesia yang mengalami disfungsi ereksi telah mencoba mengobati diri dengan berbagai obat kuat, baik tradisional maupun modern.

Pada survei pengambilan data di LambenSegala Anyar, Kecamatan Pujut Kabupaten Lombok Tengah yang telah dilakukan oleh pada Desember 2015 sebanyak 10 orang, tingkat pengetahuan tentang obat kuat paling banyak yakni pada tingkat katagori sedang sebanyak 5 responden, untuk kategori tinggi yakni sebanyak 3 responden, dan tingkat pengetahuan tentang obat kuat paling sedikit pada kategori rendah yakni 2 responden. Selain itu di Lamben-Segala Anyar banyak kepala rumah tangga sebagai pengguna obat kuat dimana kepala rumah tangga memliki latar pendidikan rendah dan usia yang beragam.

Berdasarkan permasalahan ini, tingkat pengetahuan kepala rumah tangga tentang obat kuat sangat perlu dan menarik untuk diteliti.

\section{B. METODE PENELITIAN}

Penelitian ini adalah penelitian deskriptif dengan mengukur tingkat pengetahuan tentang obat kuat. Tingkat pengetahuan yang diukur yakni pengetahuan aturan pemakaian obat kuat, cara penggunaan obat kuat, dan pengetahuan efek samping obat kuat pada kepala rumah tangga Lamben-Segala Anyar, Pujut, Lombok Tengah.

\section{Lokasi dan Waktu Penelitian}

Penelitian ini dilakukan di RT/RW Lamben Desa Segala Anyar Kecamatan Pujut Kabupaten Lombok Tengah. Penelitian ini dilaksanakan pada Januari hingga Februari 2016.

\section{Populasi dan Sampel}

Populasi dalam penelitian ini adalah kepala rumah tangga yang tinggal di RT/RW Lamben Desa Segala Anyar, Kecamatan Pujut, Lombok Tengah. Pupolasi penelitian berjumlah 93 orang. Teknik pengambilan sampel yang akan digunakan dalam penelitian ini adalah sampling jenuh dengan mengambil semua anggota populasi menjadi sampel[5].

\section{Data Penelitian}

Data penelitian terdiri atas data hasil kuesioner yang sebarkan kepada kepala rumah tangga di Lamben-Segala Anyar Kecamatan Pujut Kabupaten Lombok Tengah sebagai data primer dan daftar jumlah kepala rumah tangga di Lamben-Segala Anyar, Kecamatan Pujut Kabupaten Lombok Tengah sebagai data sekunder yang diperoleh dari Kantor Desa Segala Anyar.

\section{Instrumen dan Pengolahan Data}

Instrumen yang digunakan dalam penelitian ini menggunakan kuesioner yakni dalam bentuk pilihan ganda yang terdiri dari 9 (sembilan) pertanyaan dengan keterangan 
obat kuat dan disetiap masing-masing variabel tersebut terdiri dari 3 (tiga) item pertanyaan yakni aturan pemakian obat kuat, cara penggunaan obat kuat, efek samping obat kuat. Kuesioner diisi oleh peneliti berdasarkan jawaban wawancara dengan responden.

Pengolahan data dilakukan dengan cara:

1. menskoring tingkat pengetahuan tentang obat kuat yakni pengetahuan aturan pemakaian obat kuat, cara penggunaan obat kuat dan efek samping obat kuat diberikan skor dengan ketentuan rendah: 0-3, sedang: 4-6, dan tinggi: 7-9.

2. menghitung persentase dengan rumus:

$$
P=\frac{\sum f}{n} \times 100 \%
$$

$P \quad=$ persentase skor

$\sum f=$ frekuensi skor

$n \quad=$ jumlah responden

Kemudian hasilnya dimasukkan dalam kriteria standar penilaian dan dapat dikategorikan dari mulai tinggi, sedang, sampai kurang.

\section{HASIL DAN PEMBAHASAN}

1. Tingkat Pengetahuan Aturan Pemakaian Obat Kuat Pada Kepala Rumah Tangga

Tabel 1. Tingkat Pengetahuan Aturan Pemakaian Obat Kuat di Lamben-Segala Anyar

\begin{tabular}{|c|c|c|c|}
\hline No & $\begin{array}{c}\text { Aturan } \\
\text { pemakaian } \\
\text { obat kuat }\end{array}$ & $\begin{array}{l}\text { Frekuensi } \\
\text { (orang) }\end{array}$ & $\begin{array}{c}\text { Persentase } \\
(\%)\end{array}$ \\
\hline 1 & Tinggi & 28 & 30 \\
\hline 2 & Sedang & 40 & 43 \\
\hline 3 & Rendah & 25 & 27 \\
\hline \multicolumn{2}{|r|}{ Total } & 93 & 100 \\
\hline
\end{tabular}

Berdasarkan hasil penelitian yang ditunjukkan oleh Tabel 1 bahwa dari 93 kepala rumah tangga dengan tingkat pengetahuan aturan obat kuat paling banyak terdapat pada kategori sedang sebanyak 40 responden (43\%), pengetahuan aturan obat kuat yang sedang dan rendah hasilnya hampir sama, untuk pengetahuan sedang terdapat pada kategori Tinggi 28 responden (30\%), dan untuk pengetahuan paling sedikit terdapat pada kategori Rendah 25 responden (27\%).

Pada hasil penelitian tersebut, masih belum banyaknya responden yang mempunyai pengetahuan tentang aturan pemakaian obat kuat, dapat dipengaruhi oleh sistem komunikasi, informasi, dan edukasi. Serta dapat pula dipengaruhi oleh pengalaman atau riwayat cara penggunaan obat pada pasien atau kepala rumah tangga. Hasil ini sesuai dengan teori yang dikemukakan oleh Glanz[6], yang menyatakan bahwa pentingnya menerapkan sistem komunikasi, informasi, dan edukasi dalam dunia kesehatan, akan berpengaruh untuk meningkatkan pengetahuan pasien atau masyarakat dalam pemakaian obat. Menurut Notoatmodjo[7], riwayat atau pengalaman dalam upaya meningkatkan kesehatan dan pengobatan yang benar dapat mempengaruhi upaya pengobatan seterusnya, terutama dapat meningkatkan pengetahuan masyarakat tentang pemakaian obat yang baik dan benar.

\section{Tingkat Pengetahuan Cara Penggunaan Obat Kuat Pada Kepala Rumah Tangga}

Berdasarkan Tabel 2 menunjukkan bahwa dari 93 kepala rumah tangga dengan tingkat pengetahuan cara penggunaan obat kuat paling banyak terdapat pada kategori Tinggi sebanyak 41 responden (44\%). Pada hasil penelitian tersebut, banyaknya responden yang mempunyai pengetahuan kategori Tinggi yakni bahwa adanya kesadaran masyarakat akan pentingnya mengetahui cara penggunaan obat yang sesuai dengan anjuran dokter.

Tabel 2. Tingkat Pengetahuan Cara Penggunaan Obat Kuat di Lamben-Segala Anyar

\begin{tabular}{|c|c|c|c|}
\hline No & $\begin{array}{c}\text { Cara } \\
\text { Penggunaan } \\
\text { Obat }\end{array}$ & $\begin{array}{c}\text { Frekuensi } \\
\text { (orang) }\end{array}$ & $\begin{array}{c}\text { Persentase } \\
(\%)\end{array}$ \\
\hline 1 & Tinggi & 41 & 44 \\
\hline 2 & Sedang & 23 & 25 \\
\hline 3 & Rendah & 29 & 31 \\
\hline \multicolumn{2}{|r|}{ Total } & 93 & 100 \\
\hline
\end{tabular}

Berdasarkan hasil penelitian menunjukkan bahwa dari 93 kepala rumah tangga dengan tingkat pengetahuan cara penggunaan obat kuat, dari pengetahuan kategori Sedang dan Rendah hasilnya hampir sama Sedangkan tingkat 
pengetahuan cara penggunaan obat kuat yang sedang terdapat pada kategori Rendah 29 responden (31\%), dan tingkat pengetahuan cara penggunaan obat kuat paling sedikit terdapat pada kategori Sedang 23 responden (25\%), Pada hasil penelitian tersebut, masih kurangnya responden yang mempunyai pengetahuan cara penggunaan obat kuat bahwa masih kurangnya kesadaran masyarakat akan pentingnya mengetahui cara penggunaan obat kuat yang sesuai dengan anjuran dokter atau tenaga kesehatan.

Hasil penelitian ini sama dengan hasil penelitian Supardi, dkk.[8], yang menyatakan bahwa kesadaran masyarakat akan pentingnya mengetahui cara penggunaan yang sesuai dapat mencegah terjadinya kesalahan dalam pengobatan sendiri (self medication). Dharmasari[9], juga menyatakan bahwa tingginya pengetahuan masyarakat tentang cara penggunaan obat yang aman, tepat, dan rasional sangat mempengaruhi keberhasilan dalam pengobatan.

\section{Tingkat Pengetahuan Efek Samping Obat Kuat Pada Kepala Rumah Tangga}

Berdasarkan Tabel 3 menunjukkan bahwa dari 93 kepala rumah tangga dengan tingkat pengetahuan efek samping obat kuat paling banyak terdapat pada kategori rendah yakni 67 responden $(72 \%)$, hal ini dapat menyebabkan ketidakberhasilan pengobatan sendiri oleh masyarakat khususnya pada kepala rumah tangga akibat rendahnya pengetahuan tentang efek samping obat kuat yang dapat ditimbulkan pada masa pengobatan. Ketidaktahuan pada responden ini juga dapat disebabkan oleh kurangnya pemberian informasi oleh petugas medis seputar efek samping obat kuat. Sedangkan tingkat pengetahuan tentang efek samping obat kuat yang sedang terdapat pada kategori Tinggi 17 responden (18\%), dan tingkat pengetahiuan efek samping paling sedikit terdapat pada kategori Sedang 9 responden (10\%). Hal ini dapat menyebabkan keberhasilan pengobatan sendiri oleh masyarakat khususnya pada kepala rumah tangga akibat tingginya pengetahuan tentang efek samping obat kuat yang dapat ditimbulkan pada masa pengobatan. Pengetahuan pada responden ini juga dapat disebabkan oleh pemberian informasi dan menanyakan langsung ke petugas medis seputar efek samping obat kuat.

Tabel 3. Tingkat Pengetahuan Efek Samping Obat Kuat di Lamben-Segala Anyar

\begin{tabular}{|c|c|c|c|}
\hline No & $\begin{array}{c}\text { Efek samping } \\
\text { obat kuat }\end{array}$ & $\begin{array}{c}\text { Frekuensi } \\
\text { (orang) }\end{array}$ & $\begin{array}{c}\text { Persentase } \\
(\%)\end{array}$ \\
\hline 1 & Tinggi & 17 & 18 \\
\hline 2 & Sedang & 9 & 10 \\
\hline 3 & Rendah & 67 & 72 \\
\hline \multicolumn{2}{|c}{ Total } & 93 & 100 \\
\hline
\end{tabular}

Hasil penelitian ini sejalan dengan penelitian yang dilakukan Figueras, dkk.[10], yang menyatakan bahwa responden yang memiliki pengetahuan rendah akan efek samping yang tidak diinginkan dari pengobatan, lebih banyak melakukan pengobatan menurut sugesti diri sendiri. Dharmasari[9], dalam penelitiannya menemukan bahwa peran tenaga medis dalam memberikan informasi obat sangat mempengaruhi tingkat pengetahuan pasien dalam upaya melakukan pengobatan yang aman dan rasional. Darubekti[11], menyatakan bahwa masyarakat tidak mengetahui efek samping obat karena kurang didapatkannya informasi dari pihak tenaga kesehatan.

4. Tingkat Pengetahuan Tentang Obat Kuat Pada Kepala Rumah Tangga Di RT/RW Lamben Desa Segala Anyar

Tabel 4. Tingkat Pengetahuan Efek Samping Obat Kuat di Lamben-Segala Anyar

\begin{tabular}{|c|c|c|c|}
\hline No & Skor & $\begin{array}{c}\text { Frekuensi } \\
\text { (orang) }\end{array}$ & $\begin{array}{c}\text { Persentase } \\
(\%)\end{array}$ \\
\hline 1 & Tinggi & 27 & 29 \\
\hline 2 & Sedang & 52 & 56 \\
\hline 3 & Rendah & 14 & 15 \\
\hline \multicolumn{2}{|c|}{ Total } & 93 & 100 \\
\hline
\end{tabular}

Berdasarkan Tabel 4, skor tingkat pengetahuan tentang obat kuat dari 93 kepala rumah tangga paling banyak terdapat pada kategori Sedang 52 (56\%), sekor tingkat pengetahuan tentang obat kuat yang sedang terdapat pada kategori Tinggi 27 responden (29\%), dan sekor tingkat pengetahuan tentang 
obat kuat paling sedikit terdapat pada kategori Rendah 14 responden (15\%). Hasil penelitian ini, diketahuilah total skor untuk tingkat pengetahuan tentang obat kuat pada kepala rumah tangga di Desa Segala Anyar RT/RW Lamben, dan dari hasil tersebut menunjukkan bahwa tingkat pengetahuan responden pada kategori Sedang lebih banyak dibandingkan dengan kategori Tinggi dan Rendah, serta tingkat pengetahuan kategori Tinggi lebih besar dibandingkan dengan tingkat pengetahuan kategori Rendah, maka nilai persentase paling sedikit yaitu terdapat pada tingkat pengetahuan kategori Rendah. Pada hasil penelitian tersebut, banyaknya responden yang memiliki tingkat pengetahuan kategori tinggi, yakni dapat dipengaruhi oleh pengalaman terdahulu responden dalam upaya melakukan pengobatan. Serta dalam meningkatkan pengetahuan tentang obat kuat, pasien atau masyarakat lebih menggali informasi kepada pihak farmasis dengan secara langsung menanyakan tentang obat kuat.

Tingginya pengetahuan masyarakat terhadap obat kuat yakni dapat dipengaruhi oleh teknik pemberian pelayanan informasi, konseling, dan edukasi oleh pihak medis kepada pasien maupun masyarakat. Menurut Notoatmodjo[7], pengetahuan merupakan pemahaman secara internal berdasarkan fakta-fakta ilmiah, pengalaman atau kepercayaan tradisonal. Pengalaman menunjukkan bahwa pengetahuan itu penting tetapi tidak cukup untuk mengubah suatu tindakan karena ada faktor lain yang mempengaruhinya seperti persepsi, motivasi, keterampilan atau keahlian dan lingkungan.

\section{KESIMPULAN}

Kesimpulan yang dapat ditarik dari penelitian ini adalah 1) sebagaian besar responden dengan tingkat pengetahuan tentang aturan pemakaian obat kuat, yakni tergolong pada kategori Sedang yakni 40 responden (43\%), 2) sebagian besar responden dengan tingkat pengetahuan tentang cara penggunaan obat kuat, yakni tergolong pada kategori tinggi yakni 41 responden (44\%), 3) sebagian besar responden dengan tingkat pengetahuan tentang efek samping obat kuat tergolong pada kategori rendah yakni 67 responden $(72 \%)$, 4) sebagian besar skor responden dengan tingkat pengetahuan tentang obat kuat, terdapat pada kategori sedang yakni 52 responden (56\%).

\section{DAFTAR PUSTAKA}

[1] Kimin, S. (2002). Farmakognosi. Jilid I. Departemen Kesehatan Pusat Pendidikan Tenaga Kesehatan.

[2] Mulyadi Tedjapratna, 2010, Mitos Sekitar Obat kuat (online), http://www.dechacare.com , (4 Agustus 2012)

[3] Anief, (2000). Ilmu Meracik Obat, Teori dan Praktik. Cet. Ke-9, Gadjah Mada University Press : Yogyakarta

[4] Ragg, Mark. (2001). Obat-Obat yang Paling Sering Diresepkan. Alih Bahasa, Mutia S ; editor, A. Hadyana Pudjaatmaka dan Surya Satyanegara. Arcan : Jakarta.

[5] Hidayat, A.A.A. (2007). Metode penelitian keperawatan dan teknik analisi data. Salemba medika: Jakarta.

[6] Glanz K, Rimer B.K., Lewis F.M,. (2002). Health Behaviour And Health Education Theory, Research And Practice. Third Edition. Josses-Bass, San Francisco

[7] Notoatmodjo, Soekidjo. (2007). Promosi Kesehatan dan Ilmu Perilaku. PT Rineka Cipta : Jakarta.

[8] Supardi, S., Sampurno, O. D., Notosiswoyo, M., (2002), Pengobatan sendiri yang sesuai dengan aturan pada ibu-ibu di Jawa Barat, Bul. Penel. Kes., Vol. 30, 11-21.

[9] Dharmasari, S., (2003). Faktor-Faktor Yang Berhubungan Dengan Perilaku Pengobatan Sendiri Yang Aman, Tepat Dan Rasional Pada Masyarakat Kota Bandar Lampung Tahun 2003, Thesis, Diakses Tanggal 4 September 2015.

[10] Figueras, A., Caamano, F., Gestal-Otero, J. J, (2000), Sociodemographic factors related to selfmedication. European Journal of Epidemiology. (Online), 16 (1).

[11] Darubekti, N., (2001), Perilaku kesehatan masyarakat Desa Talang Pauh Kecamatan Pondok Kelapa Kab. Lampung. Jurnal penelitian UNIB, 7 (2), 96-103 